\title{
BIO-ECONOMIC AND QUALITATIVE IMPACT OF REDUCED HERBICIDE USE IN DIRECT SEEDED FINE RICE THROUGH MULTIPURPOSE TREE WATER EXTRACTS
}

\author{
Abdul Khaliq ${ }^{*}$, Amar Matloob ${ }^{1}$, and Yasir Riaz ${ }^{1}$
}

Weed control program should be environmentally benign and cost-effective so that reduced herbicide use can help meet these goals. Field trials were conducted to assess the bio-economic and qualitative impact of reduced doses ( 25 and $50 \%$ of label dose) of a postemergence pyrimidinyloxybenzoic acid herbicide (bispyribac-sodium) applied alone or in combination with multipurpose tree (eucalyptus [Eucalyptus camaldulensis Dehnh.], mango [Mangifera indica L.], and mulberry [Morus alba L.]) water extracts in direct seeded rice (Oryza sativa L.) fields. The label dose of bispyribac-sodium and penoxsulam along with weed control were included for comparison. Tank mixing of multipurpose tree water extracts with reduced herbicide doses accounted for $>55 \%$ suppression in weed density and $>75 \%$ in dry weight; they were quite higher than those recorded for the same herbicide doses used alone. A combination of these extracts with $50 \%$ reduced dose of bispyribac-sodium improved rice yield and quality attributes similar to the label dose of this herbicide. Despite the higher net benefits associated with label herbicide dose, the maximum marginal rate of return was achieved with a tank mix of $25 \%$ label herbicide dose with multipurpose tree water extracts.

Key words: Reduced dose, weed suppression, yield, kernel quality, Oryza sativa.

$\mathrm{D}$ irect seeding of rice (Oryza sativa L.) has the potential to attain high water productivity and eliminate the edaphic conflict in Punjab's rice-wheat (Triticum aestivum L.) cropping system (Khaliq et al., 2011a). Heavy weed infestation and shifts in weed population are major constraints in the sustainability of direct seeded rice (DSR). An appropriate weed management strategy has always been a major focus and key element for successful DSR. Such a strategy is of the utmost significance to secure yields and the involved production costs, as well as to minimize any negative effect on product quality. Good stand and high yield of dry direct seeded rice has a higher correlation with timely and effective weed control. Traditionally, weeds are controlled through cultural and/ or chemical methods. Manual weeding, though effective, is getting increasingly difficult due to labor scarcity, rising wages, and its dependence on weather conditions. Moreover, allowing weeds to reach a sufficient size to be pulled out and the presence of perennial weeds that fragment on pulling are other related concerns (Rao et al., 2007). Thus, using herbicides is obligatory for weed management in direct seeded rice (Jaya Suria et al., 2011). Several studies (Gitsopoulos and Froud-Williams, 2004; Adigun et al., 2005; Singh et al., 2006; 2008; Mahajan et

${ }^{1}$ University of Agriculture, Department of Agronomy, Faisalabad 38040, Pakistan. "Corresponding author (khaliquaf@gmail.com). Received: 23 November 2011.

Accepted: 12 May 2012. al., 2009) have concluded that chemical weed control is feasible since it is quick, easy, and economical.

Although efficient, the judicious use of herbicides has also been questioned since it is widely believed that they cause resistance in some previously susceptible weed species; serious environmental concerns also arise due to their high residual effects in the soil (Ahn et al., 2005; Khaliq et al., 2011b). An international survey conducted in 70000 fields revealed that over 383 biotypes of 208 weed species (122 dicots and 86 monocots) have evolved to be resistant to herbicides (Heap, 2012). Resistance of rice weeds to a number of herbicides has been reported (Rao et al., 2007) since they only target a few molecular sites (Duke, 1990). In fact, 270 herbicides covering the global market represent only 17 modes of action with almost half of them acting as acetolactate synthase (ALS), PS II, and Protox inhibitors (Macías et al., 2007).

A lot of work has recently focused on plant-derived materials as an alternative to herbicides (Kuk et al., 2001). Allelopathy has emerged as a potential tool and as an alternative to herbicides for weed management (Tesio and Ferrero, 2010). Multipurpose tree species with allelopathic potential can be exploited for sustainable weed management (Singh et al., 2003). Suppressive allelopathic effects of eucalyptus (Verdeguer et al., 2009), mango (Javaid et al., 2010), and mulberry (Haq et al., 2010) against weeds have recently been documented. Different plant species contain allelochemicals that vary in type and concentration (Xuan et al., 2004). Furthermore, 
allelopathic activity is attributed to the combination and interaction of numerous allelochemicals instead of a single compound (Einhellig, 1996). The allelopathic potential of plant species can be exploited in many ways. Using water extracts of these species seems to be one possible tool. Although the use of allelopathic water extracts is economical and environmentally friendly, reduction in weed biomass is less than with herbicides and manual weeding. However, it may be possible to use these allelopathic water extracts in combination or with a reduced dose of herbicides to increase their efficacy and reduce the use of herbicides (Mushtaq et al., 2010). Allelopathic substances in combination with lower doses of herbicides can be an important step in recent times.

In our preliminary studies, water extracts of these trees were found to inhibit rice weed growth (Khaliq et al., 2012). However, the suppressive effects of tank mixing these extracts have not yet been documented against weeds of direct seeded rice fields. Moreover, there is little information regarding the influence of tank mixing these water extracts in combination with a lower herbicide dose on weeds of direct seeded rice. The following study was therefore designed to evaluate the influence of allelopathic plant water extracts alone and in combination with a reduced dose of herbicide on direct seeded rice and its associated weeds.

\section{MATERIALS AND METHODS}

\section{Site description}

The proposed study was conducted at the Agronomic Research Farm, University of Agriculture Faisalabad $\left(31.25^{\circ} \mathrm{N}, 73.09^{\circ} \mathrm{E}, 184 \mathrm{~m}\right.$ a.s.1.). The soil of the experimental site belongs to the Lyallpur soil series (Aridisol-fine-silty, mixed, hyperthermic Ustalfic, Haplargid in USDA classification and Haplic Yermosols in FAO classification). Saturated soil paste $\mathrm{pH}$ was 7.7 and total soluble salts were $0.79 \mathrm{dS} \mathrm{m}^{-1}$. Organic matter, total $\mathrm{N}$, available $\mathrm{P}$ and $\mathrm{K}$ were $0.74 \%, 0.055 \%$, $7.1 \mathrm{mg} \mathrm{kg}^{-1}$, and $183 \mathrm{mg} \mathrm{kg}^{-1}$, respectively. Due to high evapotranspiration, Faisalabad features an arid climate with a mean annual rainfall of approximately $200 \mathrm{~mm}$.

\section{Experimentation}

The experiment was laid out in a randomized complete block design (RCBD) with four replicates during the summers of 2009 and 2010. The net plot size was $6 \mathrm{~m} \times$ $2.70 \mathrm{~m}$. Seed of the popular rice cv. Super basmati was obtained from the Rice Research Institute, Kala Shah Kaku. In both years, the crop was sown in the first week of July with a single row hand drill at a seed rate of $75 \mathrm{~kg}$ $\mathrm{ha}^{-1}$ and maintaining a distance of $22.5 \mathrm{~cm}$ between crop rows. A basal fertilizer dose of $125 \mathrm{~kg} \mathrm{~N}, 55 \mathrm{~kg} \mathrm{P}_{2} \mathrm{O}_{5}$, and $40 \mathrm{~kg} \mathrm{~K}_{2} \mathrm{O}$ ha $^{-1}$ was applied. Fertilizers were urea $(46 \%$ $\mathrm{N})$, diammonium phosphate $\left(18 \% \mathrm{~N}, 46 \% \mathrm{P}_{2} \mathrm{O}_{5}\right)$, and sulfate of potash $\left(50 \% \mathrm{~K}_{2} \mathrm{O}\right)$. All $\mathrm{P}$ and $\mathrm{K}$ and half of $\mathrm{N}$ were applied at sowing. The remaining half of $\mathrm{N}$ was top dressed in two splits at tillering and panicle initiation. The first irrigation was applied $10 \mathrm{~d}$ after sowing (DAS), and the crop was subsequently irrigated as and when needed; 14 irrigations were applied until crop maturity, when it was manually harvested.

\section{Extract preparation}

Eucalyptus, mulberry, and mango leaves were collected from plants available in the surrounding area. These were stored and dried in the shade to avoid possible leaching by rain water. Leaves were chopped separately with an electric fodder cutter into $2-3 \mathrm{~cm}$ pieces and soaked in water for $24 \mathrm{~h}$ at room temperature $\left(25 \pm 5^{\circ} \mathrm{C}\right)$ with a $1: 10$ ratio $(\mathrm{w} / \mathrm{v})$. The soaked material was filtered through 10 and 60 -mesh sieves. The respective leachates were boiled at $100{ }^{\circ} \mathrm{C}$ to increase the concentration by 20 times for easy handling and application; they were stored for subsequent use. Previous studies revealed that boiling did not affect the nature, relative composition, and efficacy of leachates (Jamil et al., 2009). To exclude the notion of inhibitory effects owing to $\mathrm{pH}$ and osmotic potential of the plant water extracts, these two attributes were measured for each water extract. The $\mathrm{pH}$ and electrical conductivity (EC) of these extracts was determined with digital $\mathrm{pH}$ and conductivity meters (HI 9811-5, Hannah Instruments, Woonsocket, Rhode Island, USA). The osmotic potential (-MPa) of different extract concentrations was determined by multiplying EC $\left(\mathrm{dS} \mathrm{m}^{-1}\right)$ by -0.036 . In this experiment, $\mathrm{pH}$ and osmotic potential of the different extracts ranged between 6.2 and 6.8 and -0.05 and $-0.09 \mathrm{MPa}$, respectively. The literature shows that these $\mathrm{pH}$ values and osmotic potential were unlikely to prevent plant growth and any growth inhibition was presumably thought to be due to inhibitory compounds present in such extracts (Chon et al., 2003).

\section{Treatment application}

Concentrated water extracts of each tree species at $18 \mathrm{~L} \mathrm{ha}^{-1}$ were applied alone and in combination with bispyribacsodium [2,6-bis(4,6-dimethoxypyrimidin-2-yloxy) benzoic acid] at 15 and $7.5 \mathrm{~g}^{\text {ai ha }} \mathrm{h}^{-1}$ (50 and $25 \%$ of label dose, respectively). The label dose of bispyribac-sodium (30 $\mathrm{g}$ ai $\mathrm{ha}^{-1}$ ) and penoxsulam (3-(2,2-difluoroethoxy)N-(5,8-dimethoxy[1,2,4]triazolo[1,5-c]pyrimidin-2-yl)$\alpha, \alpha, \alpha$-trifluorotoluene-2-sulfonamide) at $15 \mathrm{~g}$ ai ha-1 was used for comparison. Weed control was also maintained. Herbicides and their combinations with allelopathic plant water extracts were applied at 15 DAS the rice. Spraying was done with a Knapsack sprayer fitted with a flat fan nozzle and spray volume (300 $\left.\mathrm{L} \mathrm{ha}^{-1}\right)$ was determined by water calibration.

\section{Data collection}

Data of weed attributes (density and dry weight) were recorded for each experimental unit from two randomly 
selected quadrants $(50 \times 50 \mathrm{~cm})$ at 15 and $30 \mathrm{~d}$ after treatment (DAT). Weeds were counted and clipped from the ground surface, dried in an oven at $70{ }^{\circ} \mathrm{C}$ for $48 \mathrm{~h}$, and dry weight was recorded. Data of rice yield attributes were recorded from 15 randomly selected plants from each plot and the mean was calculated. Productive tillers $\left(\mathrm{m}^{-2}\right)$ were counted from two randomly selected sites from each plot and averaged. The crop was harvested, tied into bundles in their respective plots, and biological yield of the sun-dried samples was recorded. Each experimental plot was manually threshed and grain yield recorded ( $\left.\mathrm{ha}^{-1}\right)$. A random sample of rice kernels was taken from the production of each plot. One thousand kernels were counted manually and weighed with an electric balance.

Kernel length and width were determined with a digital Vernier caliper. Abortive, chalky, opaque, and normal kernels were separated by positioning the panicle in front of a common electric bulb fitted with a flexible stand as a light source; this is expressed as the total percentage. Kernel $\mathrm{N}$ was determined by micro-Kjeldhal digestion followed by ammonia distillation; it was transformed into kernel protein by a multiplication factor of 5.95 (AOAC, 1990). Kernel amylose contents were determined as per Juliano (1971). The intensity of blue color was read out in a UV visible spectrophotometer meter (UV-4000, ORI, Germany) at $620 \mathrm{~nm}$. The water absorption ratio (WAR) of kernels was calculated as suggested by Juliano et al. (1965):

$$
\mathrm{WAR}=\frac{\text { Weight } \text { of cooked rice }}{\text { Weight of raw rice }}
$$

\section{Statistical and economic analyses}

The data collected were subjected to Fisher's ANOVA technique with the "MSTATC" statistical package (Freed and Scott, 1986); the least significance difference test at $\mathrm{P}$ $\leq 0.05$ probability was applied to compare the differences among treatment means. Year effect was found to be non-significant so the 2-yr mean will be presented and discussed in its respective section.

Economic and marginal analyses based on variable costs and prevailing herbicide and rice market prices were carried out. Gross income and net benefit (the value of yield benefit as a result of any practice less the cost of such a practice) were calculated as described by CIMMYT
(1988). The marginal rate of return (MRR) was calculated as follows:

$$
\operatorname{MRR}(\%)=\frac{\text { Change in net benefit }}{\text { Change in variable cost }} \times 100
$$

\section{RESULTS AND DISCUSSION}

\section{Weed growth}

Field observations revealed that weed flora of the experimental site was comprised of horse purslane (Trianthema portulacastrum L.), jungle rice (Echinochloa colona [L.] Link), crowfoot grass (Dactyloctenium aegyptium L. Willd.), and barnyard grass (Echinochloa crus-galli [L.] P. Beauv.) The local climate and experimental site soil moisture regimes promoted weed diversity as well as their growth primarily because the fields were not immersed under water. The weeds that are otherwise non-native to rice fields and those normally controlled by flooding in transplanted rice were abundant in the experimental plots. Rao et al. (2007) attributed greater weed pressure in dry seeded rice to the absence of flooding, dry tillage, and alternate wetting and drying during crop establishment.

Total weed density (both narrow and broad-leaved) was significantly influenced $(\mathrm{P} \leq 0.05)$ by different treatments (Table 1); the difference was more pronounced for either one whether an herbicide dose was used alone or in combination with allelopathic plant water extracts. Tank mixing bispyribac-sodium at 15 and $7.5 \mathrm{~g}$ ai ha ${ }^{-1}$ with allelopathic plant water extracts suppressed horse purslane density by 89 and $83 \%$ and 63 and $62 \%$ at 15 and 30 DAT, respectively (Table 1). The corresponding inhibition in barnyard grass and jungle rice density ranged from $43-49 \%$ and $51-62 \%$ and $57-63 \%$ and $52-60 \%$, respectively, at these times. However, these treatments provided a small reduction in crow foot grass density. Bispyribac-sodium at 15 and $7.5 \mathrm{~g}$ ai ha ${ }^{-1}$ tank mixed with allelopathic plant water extracts also recorded similar (P $\leq 0.05$ ) total weed density. When applied alone at reduced rates, this herbicide recorded a lesser reduction in weed density in most cases. The label dose of bispyribacsodium suppressed horse purslane $(85-92 \%)$, barnyard grass (49-88\%), and jungle rice $(68-74 \%)$ density.

Table 1. Influence of multipurpose tree water extracts applied alone and in combination with reduced herbicide doses on weed density in direct seeded

\begin{tabular}{|c|c|c|c|c|c|c|c|c|c|c|c|}
\hline \multirow{2}{*}{\multicolumn{2}{|c|}{ Treatments }} & \multicolumn{10}{|c|}{ Weed density $\left(0.25 \mathrm{~m}^{-2}\right)$} \\
\hline & & \multicolumn{2}{|c|}{ Horse purslane } & \multicolumn{2}{|c|}{ Barnyard grass } & \multicolumn{2}{|c|}{ Jungle rice } & \multicolumn{2}{|c|}{ Crowfoot grass } & \multicolumn{2}{|c|}{ Total weeds } \\
\hline Extract/herbicide & Dose ha $^{-1}$ & 15 DAT & $30 \mathrm{DAT}$ & 15 DAT & 30 DAT & $15 \mathrm{DAT}$ & $30 \mathrm{DAT}$ & 15 DAT & 30 DAT & $15 \mathrm{DAT}$ & $30 \mathrm{DAT}$ \\
\hline Control (weed control) & - & $66.63 \mathrm{a}$ & $47.50 \mathrm{a}$ & $26.63 \mathrm{a}$ & $21.25 \mathrm{a}$ & $54.50 \mathrm{a}$ & $46.88 \mathrm{a}$ & $26.88 \mathrm{a}$ & $13.50 \mathrm{a}$ & $174.60 \mathrm{a}$ & $129.10 \mathrm{a}$ \\
\hline Eucalyptus+mulberry+mango leaf extracts & Each at $18 \mathrm{~L}$ & $64.38 \mathrm{a}$ & $38.13 b$ & $6.12 \mathrm{e}$ & $16.25 b$ & $29.00 \mathrm{~b}$ & $31.75 b$ & $16.63 \mathrm{~d}$ & $11.63 b$ & $116.10 \mathrm{~b}$ & $97.75 b$ \\
\hline $\begin{array}{l}\text { Eucalyptus+mulberry+mango leaf } \\
\text { extracts+bispyribac-sodium }\end{array}$ & Each at $18 \mathrm{~L}+15 \mathrm{~g}$ ai & $7.12 \mathrm{de}$ & $17.38 \mathrm{e}$ & $13.63 \mathrm{c}$ & $12.13 \mathrm{~d}$ & $23.63 \mathrm{~d}$ & $17.50 \mathrm{~d}$ & $21.38 \mathrm{~b}$ & $9.12 \mathrm{~cd}$ & $65.75 \mathrm{~d}$ & $56.13 \mathrm{e}$ \\
\hline $\begin{array}{l}\text { Eucalyptus+mulberry+mango leaf } \\
\text { extracts+bispyribac-sodium }\end{array}$ & Each at $18 \mathrm{~L}+7.5 \mathrm{~g}$ ai & $11.13 \mathrm{c}$ & $18.00 \mathrm{e}$ & $10.13 d$ & $10.38 \mathrm{e}$ & $25.88 \mathrm{c}$ & $18.63 \mathrm{~d}$ & $19.38 \mathrm{c}$ & $8.00 \mathrm{~d}$ & $66.50 \mathrm{~d}$ & $55.00 \mathrm{e}$ \\
\hline Bispyribac-sodium & $15 \mathrm{~g}$ ai & $8.25 \mathrm{~d}$ & $20.88 \mathrm{~d}$ & $14.00 \mathrm{c}$ & $14.25 \mathrm{c}$ & $22.38 \mathrm{~d}$ & $23.38 \mathrm{c}$ & $15.88 \mathrm{de}$ & $9.88 \mathrm{c}$ & $60.50 \mathrm{e}$ & $68.38 \mathrm{~d}$ \\
\hline Bispyribac-sodium & $7.5 \mathrm{~g}$ ai & $16.88 b$ & $24.75 \mathrm{c}$ & $16.00 \mathrm{~b}$ & $17.63 b$ & $29.63 b$ & $22.63 \mathrm{c}$ & $12.63 \mathrm{~g}$ & $12.13 \mathrm{ab}$ & $75.13 \mathrm{c}$ & $77.13 \mathrm{c}$ \\
\hline Bispyribac-sodium & $30 \mathrm{~g}$ ai & $5.12 \mathrm{e}$ & $7.12 \mathrm{f}$ & $3.25 f$ & 10.88de & $14.00 \mathrm{e}$ & $15.13 \mathrm{e}$ & $14.50 \mathrm{ef}$ & $8.00 \mathrm{~d}$ & $36.88 \mathrm{~g}$ & $41.13 \mathrm{f}$ \\
\hline Penoxsulam & $15 \mathrm{~g}$ ai & $2.50 \mathrm{f}$ & $4.38 \mathrm{~g}$ & $5.50 \mathrm{e}$ & $6.75 f$ & $21.63 d$ & $11.00 \mathrm{f}$ & $13.88 \mathrm{fg}$ & $4.25 \mathrm{e}$ & $43.50 \mathrm{f}$ & $26.38 \mathrm{~g}$ \\
\hline
\end{tabular}
fine rice (mean of 2009 and 2010).

DAT: Days after treatment; ai: active ingredient. Means with different letters differ significantly at $5 \%$ probability level according to LSD test. 
However, this herbicide poorly controlled (41-46\%) crow foot grass. This confirms our previous findings (Khaliq et al., 2011a) where bispyribac-sodium failed to achieve a desirable level of crow foot grass suppression. Maximum suppression in individual and total weed density at 30 DAT was recorded for penoxsulam when used at its label dose.

Weed dry weight was reduced to a significant level (P $\leq 0.05$ ) by different weed control treatments (Table 2). Allelopathic plant water extracts alone recorded a weed dry weight reduction of 48 and $33 \%$ at 15 and 30 DAT, respectively. Tank mixing these water extracts with a reduced dose of bispyribac-sodium suppressed weed density by $>75 \%$ but was lower when the same doses were applied alone. Moreover, reduced herbicide doses applied either alone or as a tank mix with allelopathic plant water extracts were more effective against broadleaf weed horse purslane (61-80\%) than barnyard grass (9-38\%), jungle rice (26-42\%), and crow foot grass (39-62\%) than the control. The label dose of bispyribacsodium exhibited a dry weight reduction of $>80 \%$ at 15 and 30 DAT. Penoxsulam was higher with 91 and $87 \%$ reduction in weed dry weight, respectively, which can be attributed to the suppression of both narrow and broadleaved weeds.

Data (Tables 1 and 2) revealed a pronounced negative influence of the eucalyptus+mango+mulberry water extracts mix against density and dry weight of different weed species. Such an inhibition can be attributed to the suppressive effect of phytotoxins present in these extracts. Nevertheless, using allelopathic plant water extracts as 'nature's own herbicide' is eye-catching as an eco-friendly weed management approach; this is contrary to bioassays carried out under controlled environments where the suppression achieved under field conditions is far below the level that can be referred to as acceptable for economical crop production. Limited activity and selectivity are still major drawbacks when working with natural herbicides (Duke et al., 2001). Bhowmik and Inderjit (2003) proposed that interaction between allelochemicals and herbicides can be exploited for weed management because of their complementary action.
This can lead to reducing the use of herbicides as farm chemicals and simultaneously help enhance the efficacy of allelopathic agents (Khaliq et al., 2012c). The present experiments demonstrated a $75 \%$ reduction in weed dry weight with the tank mix of different allelopathic plant water extracts and $50 \%$ of the herbicide label dose. Suppression of weed germination and growth is believed to arise from the simultaneous and additive action of numerous allelochemicals (Einhellig, 1996). Duke and Lydon (1993) proposed that a synergistic interaction occurs between various allelochemicals since they can replace each other on the basis of their biological exchange rate and relative potency; thus, this adds to each one's herbicidal potential when mixed (Gerig and Blum, 1991). Khanh et al. (2005) further reported that the magnitude of suppression in the allelopathic interaction is directly proportional to the dose of the allelopathic product.

Both bispyribac-sodium and penoxsulam suppressed weeds at their label dose. Bispyribac-sodium acts as an acetolactate synthase (ALS) inhibitor that retards synthesis of branch chain amino acids, such as leucine, isoleucine, and valine (Darren and Stephen, 2006). Penoxsulam retards root growth by reducing photosynthate movement from leaves to root by interfering with an ALS enzyme (Devine, 1989). Effectiveness of these herbicides against rice weeds has been reported elsewhere (Mahajan et al., 2009). Our results also demonstrated that the magnitude of weed suppression is proportional to the herbicide dose whether it was applied alone or in combination with allelopathic plant water extracts, which was altered by the type of weed flora present. Broad-leaved weeds were susceptible to even the lowest herbicide dose so their density and dry weight were reduced to a greater extent than grasses when compared with the control. However, for grassy weeds, $\geq 75 \%$ of the label dose was required to keep weed count within an acceptable limit. Other authors (Iqbal and Cheema, 2007; Mushtaq et al., 2010) reported similar findings while working with tank mixes of a reduced herbicide dose with allelopathic plant water extracts in some other field crops under similar environments. The reduction in density and dry weight was presumably due to the decline in density of horse purslane, a dominant broad-leaved

Table 2. Influence of multipurpose tree water extracts applied alone and in combination with reduced herbicide doses on weed dry weight in direct seeded fine rice (mean of 2009 and 2010 ).

\begin{tabular}{|c|c|c|c|c|c|c|c|c|c|c|c|}
\hline & & \multicolumn{10}{|c|}{ Weed dry weight $\left(\mathrm{g} 0.25 \mathrm{~m}^{-2}\right)$} \\
\hline \multicolumn{2}{|l|}{ Treatments } & \multicolumn{2}{|c|}{ Horse purslane } & \multicolumn{2}{|c|}{ Barnyard grass } & \multicolumn{2}{|c|}{ Jungle rice } & \multicolumn{2}{|c|}{ Crowfoot grass } & \multicolumn{2}{|c|}{ Total weeds } \\
\hline Extract/herbicide & Rate ha-1 & $15 \mathrm{DAT}$ & $30 \mathrm{DAT}$ & $15 \mathrm{DAT}$ & $30 \mathrm{DAT}$ & $15 \mathrm{DAT}$ & $30 \mathrm{DAT}$ & $15 \mathrm{DAT}$ & $30 \mathrm{DAT}$ & $15 \mathrm{DAT}$ & $30 \mathrm{DAT}$ \\
\hline Control (weed control) & - & $126.90 \mathrm{a}$ & $54.51 \mathrm{a}$ & $6.22 \mathrm{a}$ & $7.86 \mathrm{a}$ & $12.64 \mathrm{a}$ & $11.66 \mathrm{a}$ & $25.99 \mathrm{a}$ & $7.28 \mathrm{a}$ & $171.70 \mathrm{a}$ & $81.30 \mathrm{a}$ \\
\hline Eucalyptus+mulberry+mango leaf extracts & Each at $18 \mathrm{~L}$ & $68.90 \mathrm{~b}$ & $35.67 \mathrm{~b}$ & $2.12 \mathrm{de}$ & $5.82 \mathrm{~b}$ & $9.27 \mathrm{bc}$ & $7.78 b$ & $9.10 \mathrm{~d}$ & $5.44 \mathrm{~b}$ & $89.40 b$ & $54.70 \mathrm{~b}$ \\
\hline $\begin{array}{l}\text { Eucalyptus+mulberry+mango leaf } \\
\text { extracts+bispyribac-sodium }\end{array}$ & Each at $18 \mathrm{~L}+15 \mathrm{~g}$ ai & $16.29 \mathrm{f}$ & $7.40 \mathrm{~d}$ & $3.71 \mathrm{bc}$ & $4.24 \mathrm{~cd}$ & $7.99 \mathrm{~cd}$ & $5.40 \mathrm{~d}$ & $14.57 \mathrm{c}$ & $2.76 \mathrm{ef}$ & $42.57 \mathrm{f}$ & $19.81 \mathrm{~d}$ \\
\hline $\begin{array}{l}\text { Eucalyptus+mulberry+mango leaf } \\
\text { extracts+bispyribac-sodium }\end{array}$ & Each at $18 \mathrm{~L}+7.5 \mathrm{~g}$ ai & $27.40 \mathrm{e}$ & $7.48 \mathrm{~d}$ & $2.50 \mathrm{~cd}$ & $3.82 \mathrm{de}$ & $5.48 \mathrm{e}$ & $5.50 \mathrm{~cd}$ & $20.06 b$ & $3.26 \mathrm{de}$ & $55.44 \mathrm{e}$ & $20.06 \mathrm{~d}$ \\
\hline Bispyribac-sodium & $15 \mathrm{~g}$ ai & $42.56 \mathrm{~d}$ & $11.23 \mathrm{c}$ & $5.66 \mathrm{a}$ & $4.88 \mathrm{bc}$ & $9.39 b$ & $6.75 b c$ & $9.90 \mathrm{~d}$ & $4.47 \mathrm{bc}$ & $67.52 \mathrm{~d}$ & $27.34 \mathrm{c}$ \\
\hline Bispyribac-sodium & $7.5 \mathrm{~g}$ ai & $49.12 \mathrm{c}$ & $10.70 \mathrm{c}$ & $4.96 \mathrm{ab}$ & $4.99 \mathrm{bc}$ & $7.63 \mathrm{~d}$ & $7.06 \mathrm{~b}$ & $10.39 \mathrm{~d}$ & $3.88 \mathrm{~cd}$ & $72.12 \mathrm{c}$ & $26.63 \mathrm{c}$ \\
\hline Bispyribac-sodium & $30 \mathrm{~g}$ ai & $4.81 \mathrm{~g}$ & $3.64 \mathrm{e}$ & 1.10de & $3.18 \mathrm{ef}$ & $3.38 \mathrm{f}$ & $4.47 \mathrm{de}$ & $8.41 \mathrm{~d}$ & $2.88 \mathrm{e}$ & $17.71 \mathrm{~g}$ & $14.18 \mathrm{e}$ \\
\hline Penoxsulam & $15 \mathrm{~g}$ ai & $5.56 \mathrm{~g}$ & $2.96 \mathrm{e}$ & $1.02 \mathrm{e}$ & $2.61 f$ & $2.97 f$ & $3.60 \mathrm{e}$ & $5.32 \mathrm{e}$ & $1.80 \mathrm{f}$ & $14.87 \mathrm{~g}$ & $10.97 \mathrm{e}$ \\
\hline
\end{tabular}

DAT: Days after treatment; ai: active ingredient. Means with different letters differ significantly at 5\% probability level according to LSD test. 
weed of the experimental site. Control plots were initially taken over by this weed, and after it completed its life cycle in approximately one month it showed senescence and a decline in density. Such a decline can also be in part because of interspecific competition among weeds at later stages.

\section{Rice yield and yield components}

Weed management treatments significantly promoted rice grain yield components as compared to the control (Table $3)$. The highest number of productive tillers $\left(345 \mathrm{~m}^{-2}\right)$ was recorded when penoxsulam was applied, while the lowest $\left(122 \mathrm{~m}^{-2}\right)$ was found in the control plots. Tank mixing multipurpose tree water extracts with $50 \%$ reduced dose of bispyribac-sodium recorded a similar $(\mathrm{P} \leq 0.05)$ number of kernels per panicle, 1000-kernel weight, and grain yield to the results recorded when applying the label dose of this herbicide. Tank mixing allelopathic plant water extracts with a reduced (25 and 50\%) dose of bispyribac-sodium achieved a significantly higher grain yield as compared to the sole application of these herbicide doses. However, the highest rice grain yield $\left(2.80 \mathrm{tha}^{-1}\right)$ was achieved with penoxsulam.

Improvement in grain yield and related traits as compared to the control in the present study could be attributed to reduced weed-crop competition (Khaliq et al., 2011a), thereby attaining a higher number of productive tillers. A DSR crop does not have a head start over weeds and is a poor weed competitor, particularly during the initial establishment stage (Rao et al., 2007). Weeds usually emerge simultaneously or just after the emergence of rice and outcompete young rice seedlings due to their aggressive growth characteristics. The yield of DSR is particularly at risk due to weeds that establish early in the field. Delaying weeding beyond 20 DAS substantially reduces yield (Adigun et al., 2005; Khaliq and Matloob, 2011). Moody (1990) reported that weeds accomplish $20-30 \%$ of their growth as compared with $2-3 \%$ for the rice crop. Most of the weed flora encountered

Table 3. Influence of multipurpose tree water extracts applied alone and in combination with reduced herbicide doses on yield and yield components of direct seeded fine rice (mean of 2009 and 2010).

\begin{tabular}{lcccc}
\hline & $\begin{array}{c}\text { Productive } \\
\text { tillers }\end{array}$ & $\begin{array}{c}\text { Kernels } \\
\text { per panicle }\end{array}$ & $\begin{array}{c}1000 \text { kernel } \\
\text { weight }\end{array}$ & $\begin{array}{c}\text { Grain } \\
\text { yield }\end{array}$ \\
\hline $\mathrm{T}_{1}$ & $\mathrm{~m}^{-2}$ & & $\mathrm{~g}$ & $\mathrm{t} \mathrm{ha}^{-1}$ \\
$\mathrm{~T}_{2}$ & $122.00 \mathrm{~g}$ & $77.50 \mathrm{~d}$ & $19.18 \mathrm{~d}$ & $0.63 \mathrm{f}$ \\
$\mathrm{T}_{3}$ & $161.25 \mathrm{f}$ & $78.00 \mathrm{~cd}$ & $20.21 \mathrm{~cd}$ & $0.99 \mathrm{e}$ \\
$\mathrm{T}_{4}$ & $261.25 \mathrm{c}$ & $85.00 \mathrm{abc}$ & $21.37 \mathrm{ab}$ & $1.67 \mathrm{bc}$ \\
$\mathrm{T}_{5}$ & $251.25 \mathrm{~d}$ & $80.75 \mathrm{bcd}$ & $20.99 \mathrm{abc}$ & $1.50 \mathrm{~cd}$ \\
$\mathrm{~T}_{6}$ & $253.00 \mathrm{~d}$ & $78.25 \mathrm{~cd}$ & $20.95 \mathrm{abc}$ & $1.27 \mathrm{de}$ \\
$\mathrm{T}_{7}$ & $223.25 \mathrm{e}$ & $78.25 \mathrm{~cd}$ & $20.45 \mathrm{bc}$ & $0.99 \mathrm{e}$ \\
$\mathrm{T}_{8}$ & $269.75 \mathrm{~b}$ & $86.25 \mathrm{ab}$ & $21.44 \mathrm{~b}$ & $1.97 \mathrm{~b}$ \\
$\mathrm{LSD}$ & $345.00 \mathrm{a}$ & $90.00 \mathrm{a}$ & $21.94 \mathrm{a}$ & $2.80 \mathrm{a}$ \\
\hline
\end{tabular}

Means with different letters differ significantly at $5 \%$ probability level according to LSD test. $\mathrm{T}_{1}$ : Control (weed control); $\mathrm{T}_{2}$ : Eucalyptus+mulberry+mango leaf extracts each at $18 \mathrm{~L}$ $\mathrm{ha}^{-1} ; \mathrm{T}_{3}$ : Eucalyptus+mulberry+mango leaf extracts each at $18 \mathrm{~L} \mathrm{ha}^{-1}+$ bispyribac-sodium at $15 \mathrm{~g}$ ai ha ${ }^{-1} ; \mathrm{T}_{4}$ : Eucalyptus+mulberry+mango leaf extracts each at $18 \mathrm{~L} \mathrm{ha}^{-1}+$ bispyribacsodium at $7.5 \mathrm{~g} \mathrm{ha}^{-1} ; \mathrm{T}_{5}$ : Bispyribac-sodium at $15 \mathrm{~g}$ ai ha ${ }^{-1} ; \mathrm{T}_{6}$ : Bispyribac-sodium at $7.5 \mathrm{~g}$ ai ha $^{-1} ; \mathrm{T}_{7}$ : Bispyribac-sodium at $30 \mathrm{~g}$ ai ha ${ }^{-1} ; \mathrm{T}_{8}$ : Penoxsulam at $15 \mathrm{~g}$ ai ha ${ }^{-1}$. in the present study was comprised of highly competitive $\mathrm{C}_{4}$ weed species (Caton et al., 2004). Uncontrolled weed growth accounted for $77 \%$ loss of rice grain yield in the present study. This level of yield reduction under seasonlong weed infestation corroborates previous work done by Khaliq and Matloob (2011).

\section{Kernel quality attributes}

Kernel quality was significantly improved under different weed control treatments (Tables 4). Kernel dimension is a principal determinant of kernel quality and thin long kernels are preferred. Tank mixing allelopathic plant water extracts with a reduced herbicide dose produced quality kernels as good as those harvested when using the label herbicide dose. Uncontrolled weed spread (control plots) recorded the lowest percentage $(46.25 \%)$ of normal kernels. Nonetheless, a reverse trend was observed where weeds were controlled. Tank mixing allelopathic plant water extracts with a reduced herbicide dose recorded a similar percentage of normal kernels to that achieved with the label herbicide dose. Unmanaged weeds also reduced kernel-protein content (Table 4). It is worth mentioning that the increase in yield was accompanied with improved kernel protein content. Significantly lower amylose contents and higher water absorption ratios were recorded for all weed control treatments as compared to the control (Table 4).

Improved kernel length in the present study indicates a greater source capacity to produce photo-assimilates that were translocated and partitioned into sink. The increase in kernel quality attributes can be an outcome of better nutrient and water uptake under weed control treatments with improved fertilization and a lower number of abortive kernels (Khaliq et al., 2011a). Irshad et al. (2008) reported that reduced weed crop competition facilitates continuous translocation of carbohydrates to panicles. The improved kernel protein contents can be a result of the greater fraction of available $\mathrm{N}$ to rice plants in the absence of weeds.

Table 4. Influence of multipurpose tree water extracts applied alone and in combination with reduced herbicide rates on kernel quality attributes of direct seeded fine rice (mean of 2009 and 2010).

\begin{tabular}{|c|c|c|c|c|c|c|}
\hline & $\begin{array}{l}\text { Kernel } \\
\text { length }\end{array}$ & $\begin{array}{c}\text { Kernel } \\
\text { width }\end{array}$ & $\begin{array}{c}\text { Normal } \\
\text { kernel }\end{array}$ & $\begin{array}{l}\text { Kernel } \\
\text { protein } \\
\text { content }\end{array}$ & $\begin{array}{c}\text { Kernel } \\
\text { amylose } \\
\text { content }\end{array}$ & $\begin{array}{c}\text { Water } \\
\text { absorption } \\
\text { ratio }\end{array}$ \\
\hline & \multicolumn{2}{|c|}{$\mathrm{mm}$} & \multicolumn{3}{|c|}{$\%$} & \\
\hline $\mathrm{T}_{1}$ & $6.86 \mathrm{~d}$ & $1.49 \mathrm{c}$ & $46.25 \mathrm{~d}$ & $6.63 \mathrm{e}$ & $22.81 \mathrm{a}$ & $3.56 \mathrm{c}$ \\
\hline $\mathrm{T}_{2}$ & $8.15 \mathrm{c}$ & $1.51 \mathrm{bc}$ & $55.00 \mathrm{c}$ & $7.35 \mathrm{~cd}$ & $22.23 \mathrm{ab}$ & $3.89 \mathrm{~b}$ \\
\hline $\mathrm{T}_{3}$ & $8.35 \mathrm{bc}$ & $1.50 \mathrm{bc}$ & $57.50 \mathrm{bc}$ & $7.98 \mathrm{~b}$ & $20.28 \mathrm{~cd}$ & $4.04 \mathrm{~b}$ \\
\hline $\mathrm{T}_{4}$ & $8.34 \mathrm{bc}$ & $1.51 b c$ & $58.75 b c$ & $7.44 \mathrm{c}$ & $20.12 d$ & $3.89 \mathrm{~b}$ \\
\hline $\mathrm{T}_{5}$ & $8.35 \mathrm{bc}$ & $1.49 \mathrm{c}$ & $57.50 \mathrm{bc}$ & $6.93 \mathrm{de}$ & $21.78 \mathrm{abc}$ & $4.06 \mathrm{~b}$ \\
\hline $\mathrm{T}_{6}$ & $8.16 \mathrm{c}$ & $1.51 \mathrm{bc}$ & $55.00 \mathrm{c}$ & $7.49 \mathrm{c}$ & $20.72 \mathrm{bcd}$ & $3.86 \mathrm{~b}$ \\
\hline $\mathrm{T}_{7}$ & $8.80 \mathrm{ab}$ & $1.55 \mathrm{ab}$ & $61.25 \mathrm{~b}$ & $8.62 \mathrm{a}$ & $20.12 d$ & $4.31 \mathrm{a}$ \\
\hline $\mathrm{T}_{8}$ & $9.17 \mathrm{a}$ & $1.58 \mathrm{a}$ & $66.25 \mathrm{a}$ & $7.62 \mathrm{bc}$ & $19.32 \mathrm{~d}$ & $3.93 \mathrm{~b}$ \\
\hline LSD & 0.60 & 0.06 & 4.35 & 0.48 & 1.62 & 0.23 \\
\hline
\end{tabular}

Means with different letters differ significantly at $5 \%$ probability level according to LSD test. $\mathrm{T}_{1}$ : Control (weed control); $\mathrm{T}_{2}$ : Eucalyptus+mulberry+mango leaf extracts each at $18 \mathrm{~L}$ $\mathrm{ha}^{-1} ; \mathrm{T}_{3}$ : Eucalyptus+mulberry+mango leaf extracts each at $18 \mathrm{~L} \mathrm{ha}^{-1}+$ bispyribac-sodium at $15 \mathrm{~g} \mathrm{ai} \mathrm{ha}^{-1}, \mathrm{~T}_{4}$ : Eucalyptus+mulberry+mango leaf extracts each at $18 \mathrm{~L} \mathrm{ha}^{-1}+$ bispyribacsodium at $7.5 \mathrm{~g} \mathrm{ha}^{-1} ; \mathrm{T}_{5}$ : Bispyribac-sodium at $15 \mathrm{~g}$ ai ha- ${ }^{-1} ; \mathrm{T}_{6}$ : Bispyribac-sodium at $7.5 \mathrm{~g}$ ai $\mathrm{ha}^{-1} ; \mathrm{T}_{7}$ : Bispyribac-sodium at $30 \mathrm{~g}$ ai ha ${ }^{-1} ; \mathrm{T}_{8}$ : Penoxsulam at $15 \mathrm{~g}$ ai ha ${ }^{-1}$. 


\section{Economic and marginal returns}

The economic evaluation of any weed management practice is of paramount significance for its acceptance at the farmer level. Weed control efficiency cannot be considered as the only criterion to determine the suitability of a particular treatment; cost effectiveness of a treatment is also very important (Jaya Suria et al., 2011; Khaliq et al., 2011a). Our data showed that the highest net benefit (Rs. $89650 \mathrm{ha}^{-1}$ ) achieved as compared to the control (Table 5) was obtained by applying penoxsulam followed by bispyribac-sodium (Rs. $63108 \mathrm{ha}^{-1}$ ) at their label doses. Marginal analyses give an additional insight by focusing on the relative outcome of per unit additional investment on any particular weed control treatment. Tank mixing allelopathic plant water extracts with $25 \%$ of the label dose of bispyribac-sodium was identified as the treatment achieving a $15711 \%$ marginal rate of return (Table 6). It was closely followed by the penoxsulam (15453\%). Applying bispyribac-sodium at its label dose dominated due to lower net benefits and the higher variable costs involved. All other treatments reflected lower MRR.

\section{CONCLUSIONS}

The present work revealed a fairly acceptable level of weed suppression in a direct seeded fine rice field without a weed density increase in the following year; product quantity and quality was achieved when the reduced herbicide dose (50\%) was tank mixed with multipurpose tree water extracts. It can be used as a cost-effective, economical, and environmentally friendly approach to minimize weed pressure and production costs.

\section{ACKNOWLEDGEMENTS}

The authors are grateful to the Higher Education Commission of Pakistan for providing financial support for these studies under the National Research Program.
Table 6. Marginal and dominance analysis of different weed control treatments.

\begin{tabular}{lcccrr}
\hline $\begin{array}{l}\text { Treat- } \\
\text { ments }\end{array}$ & $\begin{array}{c}\text { Total } \\
\text { variable } \\
\text { costs }\end{array}$ & $\begin{array}{c}\text { Net } \\
\text { benefits }\end{array}$ & $\begin{array}{c}\text { Change in } \\
\text { variable } \\
\text { costs }\end{array}$ & $\begin{array}{c}\text { Change } \\
\text { in net } \\
\text { benefits }\end{array}$ & $\begin{array}{c}\text { Marginal } \\
\text { rate of } \\
\text { return }\end{array}$ \\
\cline { 2 - 5 } & 0 & 21721 & - & - & $\%$ \\
$\mathrm{~T}_{1}$ & 674.0 & 33015 & 46.2 & 69 & - \\
$\mathrm{T}_{2}$ & 1229.7 & 53829 & 277.9 & 5082 & 1829 \\
$\mathrm{~T}_{3}$ & 951.8 & 48747 & 46.1 & 7243 & 15711 \\
$\mathrm{~T}_{4}$ & 905.7 & 41504 & 231.7 & 8489 & 3664 \\
$\mathrm{~T}_{5}$ & 627.8 & 32946 & 627.8 & 11225 & 1788 \\
$\mathrm{~T}_{6}$ & 1461.5 & 63108 & 0 & - & $\mathrm{D}$ \\
$\mathrm{T}_{7}$ & 1461.5 & 89650 & 231.8 & 35821 & 15453 \\
$\mathrm{~T}_{8}$ & & & & & \\
\hline
\end{tabular}

$\mathrm{T}_{1}$ : Control (weed control); $\mathrm{T}_{2}$ : Eucalyptus+mulberry+mango leaf extracts each at $18 \mathrm{~L} \mathrm{ha}^{-1}$; $\mathrm{T}_{3}$ : Eucalyptus+mulberry+mango leaf extracts each at $18 \mathrm{~L} \mathrm{ha}^{-1}+$ bispyribac-sodium at $15 \mathrm{~g}$ ai ha-1 $; \mathrm{T}_{4}$ : Eucalyptus+mulberry+mango leaf extracts each at $18 \mathrm{~L} \mathrm{ha}^{-1}+$ bispyribac-sodium at $7.5 \mathrm{~g} \mathrm{ha}^{-1} ; \mathrm{T}_{5}$ : Bispyribac-sodium at $15 \mathrm{~g}$ ai ha $^{-1} ; \mathrm{T}_{6}$ : Bispyribac-sodium at $7.5 \mathrm{~g}^{-}$ai ha' ${ }^{-1} ; \mathrm{T}_{7}$ : Bispyribac-sodium at $30 \mathrm{~g}$ ai ha- ${ }^{-1} ; \mathrm{T}_{8}$ : Penoxsulam at $15 \mathrm{~g}$ ai ha ${ }^{-1}$, D: Dominated due to less benefits than preceding treatments (higher costs and lower net benefits); 1US $\$=91.10$ Rs.

Impacto bioeconómico y cualitativo del uso reducido de herbicidas en arroz de siembra directa a través de extractos acuosos de árboles multipropósito. Los programas de control de malezas deben ser respetuosos del medio ambiente y rentables, y la reducción del uso de herbicidas puede ayudar a cumplir estas metas. Los ensayos de campo se llevaron a cabo para evaluar el impacto bioeconómico y cualitativo de dosis reducidas ( 25 y $50 \%$ de la dosis etiqueta) de un herbicida de postemergencia pirimidiniloxi benzoico (bispiribac-sodio) aplicado solo o en combinación con extractos acuosos de árboles multipropósito [eucalipto (Eucalyptus camaldulensis Dehnh.), mango (Mangifera indica L.), morera (Morus alba L.)] en campos de arroz (Oryza sativa L.) de siembra directa. Se incluyó dosis recomendada en la etiqueta de bispiribac-sodio y penoxsulam y un control de malezas para comparación. Mezcla de estanque de los extractos acuosos de árboles multipropósito con dosis de herbicida reducida causó supresión de $>55 \%$ en densidad de malezas y $>75 \%$ en peso seco, lo que fue superior cuando estas dosis de herbicida se utilizaron solas. La combinación de estos extractos con un $50 \%$ de reducción de la dosis de bispiribac-sodio registró granos por panícula, peso 1000 granos y rendimiento de grano

Table 5. Economic analysis of different weed control treatments.

\begin{tabular}{|c|c|c|c|c|c|c|c|c|c|}
\hline Treatments & $\mathrm{T}_{1}$ & $\mathrm{~T}_{2}$ & $\mathrm{~T}_{3}$ & $\mathrm{~T}_{4}$ & $\mathrm{~T}_{5}$ & $\mathrm{~T}_{6}$ & $\mathrm{~T}_{7}$ & $\mathrm{~T}_{8}$ & Remarks \\
\hline Paddy yield & 0.63 & 0.99 & 1.67 & 1.50 & 1.27 & 0.99 & 1.97 & 2.80 & tha $^{-1}$ \\
\hline $10 \%$ loss (paddy) & 0.063 & 0.099 & 0.167 & 0.150 & 0.127 & 0.099 & 0.197 & 0.280 & To bring at farmer level \\
\hline Adjusted paddy yield & 0.567 & 0.891 & 1.503 & 1.35 & 1.143 & 0.891 & 1.773 & 2.52 & $10 \%$ discount \\
\hline Income from paddy yield & 19136 & 30071 & 50726 & 45562 & 38576 & 30071 & 59838 & 85050 & Rs. $33750 \mathrm{t}^{-1}$ \\
\hline Straw yield & 3.83 & 5.36 & 6.42 & 6.13 & 5.68 & 5.19 & 7.01 & 8.98 & tha $^{-1}$ \\
\hline $10 \%$ loss (straw) & 0.383 & 0.536 & 0.642 & 0.613 & 0.568 & 0.519 & 0.710 & 0.898 & To bring at farmer level \\
\hline Adjusted straw yield & 3.447 & 4.824 & 5.778 & 5.517 & 5.112 & 4.671 & 6.309 & 8.082 & $10 \%$ discount \\
\hline Income from straw yield & 2585 & 3618 & 4333 & 4137 & 3834 & 3503 & 4731 & 6061 & Rs. $750 \mathrm{t}^{1}$ \\
\hline Gross income & 21721 & 33689 & 55059 & 49699 & 42410 & 33574 & 64569 & 91111 & Rs. ha ${ }^{-1}$ \\
\hline Cost of extract & - & 324 & 324 & 324 & - & - & - & - & Rs.108 per $18 \mathrm{~L}$ of each extract \\
\hline Cost of penoxsulam & - & - & - & - & - & - & - & 1111.5 & Rs. $1111.5 \mathrm{ha}^{-1}$ \\
\hline Cost of bispyribac-sodium & - & - & 555.7 & 277.8 & 555.7 & 277.8 & 1111.5 & & Rs. $1111.5 \mathrm{ha}^{-1}$ \\
\hline Cost of spray application & - & 250 & 250 & 250 & 250 & 250 & 250 & 250 & Rs. 250 per man, one man $\mathrm{d}^{-1} \mathrm{ha}^{-1}$ \\
\hline Cost of spray rental & & 100 & 100 & 100 & 100 & 100 & 100 & 100 & Rs. 100 per spray \\
\hline Variable costs & 0 & 674 & 1229.7 & 951.8 & 905.7 & 627.8 & 1461.5 & 1461.5 & Rs. ha ${ }^{-1}$ \\
\hline Net benefits & 21721 & 33015 & 53829 & 48747 & 41504 & 32946 & 63108 & 89650 & Rs. ha ${ }^{-1}$ \\
\hline
\end{tabular}

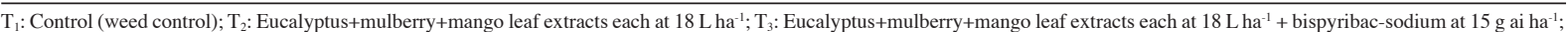
$\mathrm{T}_{4}$ : Eucalyptus+mulberry+mango leaf extracts each at $18 \mathrm{~L} \mathrm{ha}^{-1}+$ bispyribac-sodium at $7.5 \mathrm{~g} \mathrm{ha}^{-1} ; \mathrm{T}_{5}$ : Bispyribac-sodium at $15 \mathrm{~g}$ ai ha ${ }^{-1} ; \mathrm{T}_{6}: \mathrm{Bispyribac}$-sodium at $7.5 \mathrm{~g}$ ai ha ${ }^{-1} ; \mathrm{T}_{7}: \mathrm{Bispyribac}$ sodium at $30 \mathrm{~g}$ ai ha ${ }^{-1} ; \mathrm{T}_{8}$ : Penoxsulam at $15 \mathrm{~g}$ ai ha $^{-1} ; 1 \mathrm{US} \$=91.10 \mathrm{Rs}$. 
similar a la dosis de etiqueta del herbicida superiores a la aplicación de dosis reducida de este herbicida. Este tratamiento también mejoró los atributos de calidad del grano sobre el control similar a la dosis de etiqueta del herbicida. A pesar de los mayores beneficios netos de la dosis de etiqueta del herbicida, la tasa máxima marginal de retorno se obtuvo con mezcla de estanque de $25 \%$ de la dosis herbicida sugerida con extractos acuosos vegetales multipropósito.

Palabras clave: dosis reducida, supresión de malezas, rendimiento, calidad de grano, Oryza sativa.

\section{LITERATURE CITED}

Adigun, J.A., T.S.O. Lagoke, and I.D. Adekpe. 2005. Efficacy of selected herbicides for weed control in rain-fed upland rice in the Nigerian Northern Guidea Savanna. Agricultura Tropica et Subtropica 38:99-104

Ahn, J.K., S.J. Hahn, J.T. Kim, T.D. Khanah, and I.M. Chung. 2005. Evaluation of allelopathic potential among rice (Oryza sativa L.) germplasm for control of Echinochloa crus-galli P. Beauv. in the field. Crop Protection 24:413-419.

AOAC. 1990. Official methods of analysis. $15^{\text {th }}$ ed. Association of Official Analytical Chemists (AOAC), Arlington, Virginia, USA.

Bhowmik, P.C., and S. Inderjit. 2003. Challenges and opportunities in implementing allelopathy for natural weed management. Crop Protection 22:661-671.

Caton, B.P., M. Mortimer, and J.H. Hill. 2004. A practical guide to weeds of rice in Asia. International Rice Research Institute (IRRI), Los Baños, Laguna, Philippines.

Chon, S.U., Y.M. Kim, and J.C. Lee. 2003. Herbicidal potential and quantification of causative allelochemicals from several Compositae weeds. Weed Research 43:444-450.

CIMMYT. 1988. From agronomic data to farmer recommendations: An economics training manual. Centro Internacional de Mejoramiento de Maíz y Trigo (CIMMYT), Mexico D.F., Mexico.

Darren, W.L., and E.H. Stephen. 2006. Foliar and root absorption and translocation of bispyribac-sodium in cool-season turf grass Weed Technology 20:1015-1022.

Devine, M.D. 1989. Phloem translocation of herbicides. Review in Weed Science 4:191-225.

Duke, S.O. 1990. Overview of herbicide mechanisms of action. Environmental Health Perspectives 87:263-271.

Duke, S.O., and J. Lydon. 1993. Natural phytotoxins as herbicides. p. 111-121. In Duke, S.O., J.J. Menn, and J.R. Plimmer (eds.) Pest control with enhanced environmental safety. ACS Symposium Series 524. American Chemical Society, Washington, D.C., USA.

Duke, S.O., B.E. Scheffler, and F.E. Dayan. 2001. Allelochemicals as herbicides. p. 47-59. In Bonjoch, N.P., and M.J. Reigosa (eds.) $1^{\text {st }}$ European OECD Allelopathy Symposium: Physiological Aspects of Allelopathy, Vigo, Spain. Gamesal S.A., Vigo, Spain.

Einhellig, F.A. 1996. Interactions involving allelopathy in cropping systems: Allelopathy in cropping systems. Agronomy Journal 88:883-893.

Freed, R.D., and D.E. Scott. 1986. MSTATC. Crop and Soil Science Department, Michigan State University, Michigan, USA.

Gerig, T.M., and U. Blum. 1991. Effects of mixture of four phenolic acids on leaf area expansion of cucumber seedlings grown in Portsmouth $B_{1}$ soil materials. Journal of Chemical Ecology 17:29-40.

Gitsopoulos, T.K., and R.J. Froud-Williams. 2004. Effect of oxadiargyl on direct-seeded rice and Echinochloa crus-galli under aerobic and anaerobic conditions. Weed Research 44:329-334.

Haq, R.A., M. Hussain, Z.A. Cheema, M.N. Mushtaq, and M. Farooq. 2010. Mulberry leaf water extract inhibits bermudagrass and promotes wheat growth. Weed Biology and Management 20:234-240.
Heap, I. 2012. The International Survey of Herbicide Resistant Weeds. Available at http://www.weedscience.org/In.asp (accessed 12 May 2012)

Iqbal, J., and Z.A. Cheema. 2007. Effect of allelopathic crops water extracts on glyphosate dose for weed control in cotton (Gossypium hirsutum L.). Allelopathy Journal 19:403-410.

Irshad, A., Z.A. Cheema, and M. Farooq. 2008. Influence of nitrogen on interference of barnyard grass (Echinochloa crus-galli L.) with transplanted rice. Archives of Agronomy and Soil Science 54:493505.

Jamil, M., Z.A. Cheema, M.N. Mushtaq, M. Farooq, and M.A Cheema. 2009. Alternative control of wild oat and canary grass in wheat fields by allelopathic plant water extracts. Agronomy for Sustainable Development 29:475-482.

Javaid, A., S. Shafique, Q. Kanwal, and S. Shafique. 2010. Herbicidal activity of flavonoids of mango leaves against Parthenium hysterophorus L. Natural Product Research 24:1865-1875.

Jaya Suria, A.S.M., A.S. Juraimi, M.M. Rahman, A.B. Man, and A. Selamat. 2011. Efficacy and economics of different herbicides in aerobic rice system. African Journal of Biotechnology 10:80078022 .

Juliano, B.O. 1971. A simplified assay for milled rice amylose. Cereal Science Today 16:334-338.

Juliano, B.O., L.U. Onate, and A.M. Mundo. 1965. Relation of starch compaction, protein content and gelatinization temperatures to cooking and eating quality of milled rice. Food Technology 19:1006-1101.

Khaliq, A., and A. Matloob. 2011. Weed crop competition period in three fine rice cultivars under direct seeded rice culture. Pakistan Journal of Weed Science Research 17:229-243.

Khaliq, A., A. Matloob, Z.A. Cheema, and M. Farooq. 2011b. Allelopathic activity of sole and mix incorporation of crop residues against rice and its associated grassy weed-jungle rice (Echinochloa colona [L.] Link). Chilean Journal of Agricultural Research 71:418-423.

Khaliq, A., A. Matloob, M.B. Khan, and A. Tanveer. 2012 Differential suppression of rice weed by allelopathic plant water extracts. Planta Daninha. In Press.

Khaliq, A., A. Matloob, H.M. Shafique, M. Farooq, and A. Wahid 2011a. Evaluating sequential application of pre and post emergence herbicides in dry seeded fine rice. Pakistan Journal of Weed Science Research 17:111-123.

Khanh, T.D., M.I. Chung, T.D. Xuan, and S. Tawata. 2005. The exploitation of crop allelopathy in sustainable agricultural production. Journal of Agronomy and Crop Science 191:172-184

Kuk, Y.I., N.R. Burgos, and R.E. Talbert. 2001. Evaluation of rice by-products for weed control. Weed Science 49:141-149.

Macías, F.A., J.M.G. Mollinilo, R.M. Verala, and J.C.G. Galindo. 2007. Allelopathy-a natural alternative for weed management Pest Management Science 63:327-348.

Mahajan, G., B.S. Chauhan, and D.E. Johnson. 2009. Weed management in aerobic rice in Northwestern Indo-Gangetic Plains. Journal of Crop Improvement 23:366-382.

Moody, K. 1990. Post-planting weed control in direct-seeded rice. Rice Symposium. 25-27 September 1990. Malaysian Agricultural Research and Development Institute (MARDI), Penang, Malaysia

Mushtaq, M.N., Z.A. Cheema, A. Khaliq, and M.R. Naveed. 2010. A $75 \%$ reduction in herbicide use through integration with sorghum+sunflower extracts for weed management in wheat. Journal of the Science of Food and Agriculture 90:1897-1904.

Rao, A.N., D.E. Jhonson, B. Sivaprasad, J.K. Ladha, and A.M. Mortimer. 2007. Weed management in direct seeded rice. Advances in Agronomy 93:153-255.

Singh, H.P., D.R. Batish, and R.K. Kohli. 2003. Allelopathic interactions and allelochemicals: new possibilities for sustainable weed management. Critical Reviews in Plant Sciences 22:239311.

Singh, S., L. Bhushan, J.K. Ladha, R.K. Gupta, A.N. Rao, and B. Sivaprasad. 2006. Weed management in dry seeded rice (Oryza sativa) cultivated in the furrow irrigated raised bed planting system. Crop Protection 25:487-495. 
Singh, S., J.K. Ladha, R.K. Gupta, L. Bushan, and A.N. Rao. 2008. Weed management in aerobic rice systems under varying establishment methods. Crop Protection 27:660-671.

Tesio, F., and A. Ferrero. 2010. Allelopathy, a chance for sustainable weed management. International Journal of Sustainable Development \& World Ecology 17:377-389.

Verdeguer, M., M.A. Blázquez, and H. Boira. 2009. Phytotoxic effects of Lantana camara, Eucalyptus camaldulensis and Eriocephalus africanus essential oils in weeds of Mediterranean summer crops. Biochemical Systematics and Ecology 37:362-369.
Xuan, T.D., E. Tsuzuki, S. Tawata, and T.D. Khanh. 2004. Methods to determine allelopathic potential of crop plants for weed control. Allelopathy Journal 13:149-164 